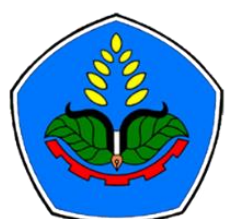

AGROPROSS

National Conference

Proceedings of Agriculture
Proceedings:

Peningkatan Produktivitas Pertanian Era Society 5.0 Pasca Pandemi

Tempat : Politeknik Negeri Jember

Tanggal : 22 Juli 2021

Publisher :

Agropross, National Conference Proceedings of Agriculture

ISBN : 978-623-94036-6-9

DOI : 10.25047 /agropross.2021.228

\title{
Respon Perkecambahan dan Pertumbuhan Bunga Telang (Clitoria ternatea L.) Terhadap Asal Benih dan Berbagai Perlakuan Pematahan Dormansi
}

\author{
Author(s): Hawari ${ }^{(1)^{*}}$, Bambang Pujiasmanto ${ }^{(2)}$, Eddy Triharyanto ${ }^{(2)}$ \\ (1) Mahasiswa S2 Program Studi Agronomi, Fakultas Pertanian, Universitas Sebelas Maret \\ (2) Staf Dosen Program Studi Agronomi, Fakultas Pertanian, Universitas Sebelas Maret \\ * Corresponding author: hawarinew3@gmail.com
}

\section{ABSTRACT}

Telang flower (Clitoria ternatea L.) is one of the leguminous plants that has various pharmacological potentials, but this plant has not been widely cultivated and most of its harvests still come from nature. Telang flower propagation using seeds has a period of dormancy, so efforts are needed to break the dormancy of telang flower seeds. This study aimed to determine the effect of seed origin and various treatments of breaking dormancy on germination and growth of telang flower. This research was conducted at the screen house of the Faculty of Agriculture, Sebelas Maret University in April - May 2021. It was applied FRBD consisting of the first factor of seed origin (K), namely the origin of seeds from the lowlands (K1) and highlands (K2). both treatments $(P)$ were control treatment $(P 1)$, immersion temperature of $45^{\circ} \mathrm{C}(P 2)$ and $G A 3$ solution with a concentration of $30 \mathrm{ppm}(\mathrm{P} 3)$. The data obtained were analyzed using analysis of variance and followed by LSD 5\%. The results showed that there was no interaction between seed origin and dormancy breaking treatment. Seed origin treatment gave the highest value on the parameters of growth speed (22.01\%/etmal), simultaneous growth (79.17\%), the number of leaves aged 1 WAP (2.17 leaves), 2 MST (9.42 strands), 3 MST (21.83 strands), 4 MST (44.33 strands) and 5 MST (81.50 strands). Meanwhile, treatment with GA3 solution with a concentration of 30 ppm (P3) gave the highest value for the parameters of germination (100\%) and plant height at 2 MST (19.77 cm).
\end{abstract}

Keywords:

Origin of seeds;

Clitoria

ternatea L.;

Treatment

\section{Kata Kunci: ABSTRAK}

Asal benih;

Bunga telang (Clitoria ternatea $\mathrm{L}$.) merupakan salah satu tumbuhan leguminosae yang memiliki berbagai potensi farmakologis, namun tumbuhan ini belum dibudidayakan secara luas dan

Clitoria ternatea L.; biji memiliki masa dormansi, sehingga diperlukan upaya untuk pematahan dormansi benih bunga telang. Penelitian ini bertujuan untuk mengetahui pengaruhasal benih dan berbagai perlakuan

Perlakuan pematahan dormansi terhadap perkecambahan dan pertumbuhan bunga telang. Penelitian ini dilakukan di screen house Fakultas Pertanian Universitas Sebelas Maret pada bulan April - Mei 2021. Metode penelitian menggunakan RAK faktorial yang terdiri dari faktor pertama asal benih (K) yaitu asal benih dari dataran rendah $\left(\mathrm{K}_{1}\right)$ dan dataran tinggi $\left(\mathrm{K}_{2}\right)$, faktor kedua perlakuan $(\mathrm{P})$ yaitu perlakuan kontrol $\left(\mathrm{P}_{1}\right)$, suhu perendaman $45^{\circ} \mathrm{C}\left(\mathrm{P}_{2}\right)$ dan larutan $\mathrm{GA}_{3}$ konsentrasi $30 \mathrm{ppm}$ $\left(\mathrm{P}_{3}\right)$. Data yang diperoleh dianalisis menggunakan analysis of variance (ANOVA) dan diuji lanjut dengan BNT 5\%. Hasil penelitian menunjukkan bahwa tidak ada interaksi antara asal benih dengan perlakuan pematahan dormansi. Perlakuan asal benih memberikan nilai tertinggi pada parameter kecepatan tumbuh $(22,01 \%$ /etmal), keserempakan tumbuh $(79,17 \%)$, jumlah daun umur 1 MST (2,17 helai), 2 MST (9,42 helai), 3 MST (21,83 helai), 4 MST (44,33 helai) dan 5 MST (81,50 helai). Sedangkan perlakuan dengan larutan $\mathrm{GA}_{3}$ konsentrasi $30 \mathrm{ppm}\left(\mathrm{P}_{3}\right)$ memberikan nilai tertinggi pada parameter daya berkecambah (100\%) dan tinggi tanaman umur 2 $\operatorname{MST}(19,77 \mathrm{~cm})$. 


\section{PENDAHULUAN}

Bunga telang (Clitoria ternatea L.) merupakan salah satu tanaman leguminosae yang berasal dari Asia Tropis dan sekarang penyebarannya telah sampai Amerika Selatan (Dalimartha, 2008), Afrika, Brazil, Pasifik Utara dan Amerika Utara (United States Departement of Agriculture, 2020). Sementara di Indonesia daerah penyebarannya adalah terutama di Jawa, Sumatera, Maluku dan Sulawesi (Balai Penelitian Tanaman Rempah dan Obat, 2020).

Pemanfaatan bunga telang secara tradisional dikenal sebagai obat mata dan pewarna makanan. Namun juga memiliki potensi farmakologis sebagai antioksidan, antibakteri, anti inflamasi dan analgesik, antiparasit dan antisida, anti diabetes, anti kanker dan berperan dalam susunan syaraf pusat (Mukherjee et al., 2008). Kandungan bunga telang diantaranya adalah tanin, flobatanin, karbohidrat, saponin, triterpenoid, fenol, flavonoid, flavanol glikosida, protein, alkaloid, antisianin, minyak volatil dan steroid. Kandungan flavonoid bunga telang merupakan senyawa metabolit sekunder yang berkasiat sebagai anti oksidan (Budiasih, 2017; Manjula et al., 2013); Ponnusamy et al., 2015).

Menurut (Sutedi, 2013), bunga telang merupakan tanaman leguminosa yang cepat pertumbuhannya, dapat menutupi tanah dalam waktu 30-40 hari setelah tanam dan menghasilkan biji pada umur 110-150 hari. Persistensi $C$. ternatea sangat tinggi terhadap perubahan musim, kondisi lahan dan sangat cocok berasosiasi dengan tanaman lain seperti rumputrumputan ataupun dengan jenis leguminosa lainnya. Bunga telang tumbuh pada berbagai jenis tanah dengan ketinggian tempat antara 1-1800 mdpl (Balai Penelitian Tanaman Rempah dan Obat, 2020; Heuzé et al., 2016), terutama pada tanah berpasir dan tanah liat merah dengan kisaran $\mathrm{pH}$ tanah 5,5-8,9 dengan curah hujan rata-rata $2000 \mathrm{~mm} /$ tahun. Tumbuh baik pada kisaran suhu $19-28^{\circ} \mathrm{C}$, namun mentolerir suhu rendah $15^{\circ} \mathrm{C}$ dan tahan terhadap kekeringan 5-6 bulan di daerah tropis(Cook et al., 2005).

Tumbuhan bunga telang memiliki prospek yang sangat tinggi. Kasiat obat dan sifat alaminya memiliki potensi dalam pengembangan obat tradisional, namun tumbuhan ini belum dibudidayakan secara luas dan sebagian besar pemanenannya masih berasal dari alam (Balai Penelitian Tanaman Rempah dan Obat, 2020). Perbanyakan bunga telang dapat dilakukan dengan cara generatif yaitu menggunakan biji, namun benih telang memiliki masa dormansi hal ini dikarenakan sifat biji yang keras (Cook et al, 2005). Menurut Sutopo (2002), dormansi pada benih dapat disebabkan oleh keadaan fisik dari kulit biji, keadaan fisiologis dari embrio atau kombinasi dari kedua keadaan tersebut. Adapun upaya yang diterapkan untuk pematahan dormansi yaitu dengan perendaman air panas dengan tujuan melunakkan kulit benih sehingga mempermudah masuknya air ke dalam benih (imbibisi) dan embrio dapat segera tumbuh.

Hasil penelitian (Situmeang et al., 2014) bahwa perlakuan suhu perendaman $45^{\circ} \mathrm{C}$ selama 10 menit menghasilkan daya berkecambah benih kedelai tertinggi yaitu $95,15 \%$ dan dapat mengurangi serangan patogen jenis jamur. Selanjutnya benih Swartzia madagascariensisatau kacang ular dengan lama perendaman 10 menit menunjukkan daya berkecambah tertinggi (Amri, 2010). Selain itu pemberian ZPT juga dapat berfungsi memacu pertumbuhan benih. ZPT adalah senyawa organik bukan nutrisi tanaman, aktif dalam konsentrasi rendah yang dapat merangsang, menghambat atau merubah pertumbuhan dan perkembangan tanaman (Rajiman, 2018) diantaranya yaitu GA3. Hasil penelitian (Dewi, 2015) bahwa pemberian $\mathrm{GA}_{3}$ dengan konsentrasi 30 ppm selama 8 
jam memberikan daya berkecambah tertinggi yaitu $97 \%$ pada tanaman kacang hijau. Penelitian ini bertujuan untuk mengetahui pengaruh asal benih dan berbagai perlakuan pematahan dormansi terhadap perkecambahan dan pertumbuhan bunga telang.

\section{BAHAN DAN METODE}

Pelaksanaan penelitian dilaksanakan di Screen House Fakultas Pertanian Universitas Sebelas Maret pada bulan April sampai Mei 2021. Bahan yang digunakan yaitu benih bunga telang, media tanam yaitu tanah: pupuk kandang dan tanah (1:1:1), plastik, air perendaman $45^{\circ} \mathrm{C}$, larutan $\mathrm{GA}_{3}$ konsentrasi $30 \mathrm{ppm}$ dan polybag. Alat yang digunakan adalah gunting, penggaris, meteran,pisau, kertas label, camera, ajir, alat tulis dan gembor.

Rancangan penelitian yang digunakan adalah Rancangan Acak Kelompok faktorial yang terdiri dari 2 faktor yaitu: faktor pertama asal benih (K) terdiri dari dataran rendah/ $<400 \mathrm{mdpl}\left(\mathrm{K}_{1}\right)$ dan dataran tinggi/800 mdpl $\left(\mathrm{K}_{2}\right)$. Untuk faktor kedua perlakuan pematahan dormansi $(\mathrm{P})$ terdiri dari air biasa atau kontrol $\left(\mathrm{P}_{1}\right)$, suhu perendaman $45^{\circ} \mathrm{C}\left(\mathrm{P}_{2}\right)$ dan larutan $\mathrm{GA}_{3} 30 \mathrm{ppm}\left(\mathrm{P}_{3}\right)$. Sehingga diperoleh 6 kombinasi perlakuan yaitu:

$\mathrm{K} 1 \mathrm{P} 1=$ dataran rendah + air

$\mathrm{K} 1 \mathrm{P} 2=$ dataran rendah + suhu perendaman $45^{\circ} \mathrm{C}$

$\mathrm{K} 1 \mathrm{P} 3=$ dataran rendah + larutan $\mathrm{GA}_{3} 20$ ppm

$\mathrm{K} 2 \mathrm{P} 1=$ dataran tinggi + air

$\mathrm{K} 2 \mathrm{P} 2$ = dataran tinggi + suhu perendaman $45^{\circ} \mathrm{C}$

$\mathrm{K} 2 \mathrm{P} 3=$ dataran tinggi $+\mathrm{GA}_{3} 20 \mathrm{ppm}$ Masing-masing kombinasi perlakuan tersebut diulang sebanyak empat kali sehingga diperoleh 24 unit percobaan.

\section{Persiapan media tanam}

- Mencampurkan media tanah, pupuk kandang dan pasir secara merata
- Kemudian media diratakan dan disiram dengan air sampai jenuh.

Perendaman dan penanaman benih tanaman telang

- Menyiapkan gelas kecil untuk perendaman benih bunga telang.

- Menyiapkan air dengan perlakuan perendaman masing-masing yaitu air, air dengan suhu $45^{\circ} \mathrm{C}$ dan larutan $\mathrm{GA}_{3}$ 30 ppm pada gelas kecil.

- Benih dimasukkan ke dalam masingmasing perlakuan, perlakuan dengan air selama $1 \mathrm{jam}$, perendaman dengan suhu $45^{\circ} \mathrm{C}$ selama 10 menit dan perendaman dengan larutan $\mathrm{GA}_{3} 30$ ppm selama 8 jam kemudian dikeringanginkan.

- Membuat lubang penanaman dengan kedalaman sekitar $1 \mathrm{~cm}$ lalu ditutup dengan tanah.

- Pemberian label setiap perlakuan dan ulangan.

- Melakukan pengamatan.

Pemeliharaan

Penyiraman menggunakan gembor yang dilakukan sesuai dengan kondisi media tanam. Dan pengendalian gulma dilakukan secara mekanis (pencabutan).

\section{Variabel Pengamatan}

Daya berkecambah (\%)

Daya berkecambah benih dilakukan pada hari ke-5 dan hari ke-8. Dengan rumus sebagai berikut:

DB $(\%)=\underline{\Sigma \text { Kecambah Normal }} \quad \mathrm{x}$ $100 \%$

$\Sigma$ Benih yang dikecambahkan

\section{Kecepatan tumbuh (\%/etmal)}

Kecepatan tumbuh dilakukan dengan menghitung kecambah normal setiap hari mulai dari hari ke-5 sampai hari ke-8.

$$
\mathrm{KcT}=\frac{\sum \text { Kecambah Normal }}{\sum \text { Benih yang dikecambahkan }}
$$
Etmal 
Keserempakan tumbuh (\%)

Keserempakan tumbuh dihitung dengan persentase kecambah normal di hari ke-7 pada uji daya berkecambah.

KsT $=\sum$ Kecambah normal hari ke-n $\times 100 \%$

$\Sigma$ Benih yang dikecambahkan

\section{Tinggi tanaman (cm)}

Tinggi tanaman diukur yaitu mulai dari pangkal batang utama sampai dengan titik tumbuh paling atas. Pengamatan tinggi tanaman dilakukan setiap minggu sekali mulai dari 1 MST sampai minggu terakhir pertumbuhan bunga telang.

\section{Jumlah daun (helai)}

Jumlah daun yang dihitung adalah yang membuka sempurna, dihitung setiap minggu sekali mulai dari 1 MST sampai minggu terakhir pertumbuhan bunga telang.

Data hasil penelitian meliputi pengamatan perkecambahan dan pertumbuhan bunga telang dianalisis menggunakan Analysis of Variance (ANOVA) dengan uji $\mathrm{f}$ taraf $5 \%$ untuk mengetahui pengaruh dari masing-masing perlakuan, kemudian dilakukan uji Beda Nyata Terkecil (BNT) pada taraf 5\% untuk mengetahui perbedaan rata-rata dari masing-masing perlakuan.

\section{HASIL DAN PEMBAHASAN \\ Daya Berkecambah (\%)}

Parameter pengujian daya berkecambah dilakukan dengan menghitung persentase benih yang tumbuh menjadi kecambah normal pada pengamatan first count yaitu hari ke-5 dan final count yaitu hari ke-8 setelah semai. Berdasarkan hasil sidik ragam menunjukkan bahwa perlakuan $\left(\mathrm{P}_{3}\right)$ memberikan pengaruh berbeda sangat nyata $(* *)$ terhadap F-hitung pada parameter tersebut. Perlakuan yang memberikan persentase daya berkecambah paling tinggi terdapat pada perlakuan $\mathrm{GA}_{3}$, sehingga dilakukan uji lanjut Beda Nyata
Terkecil (BNT) taraf 5\% yang tersaji dalam Tabel 1. di bawah ini.

Tabel 1. Hasil Uji Lanjut Perlakuan Terhadap Parameter Daya Berkecambah Bunga Telang (\%)

\begin{tabular}{cc}
\hline Perlakuan & Daya Berkecambah $(\%)$ \\
\hline $\mathrm{P}_{1}$ & $68,75 \mathrm{a}$ \\
$\mathrm{P}_{2}$ & $93,75 \mathrm{ab}$ \\
$\mathrm{P}_{3}$ & $100 \mathrm{~b}$ \\
\hline
\end{tabular}

Keterangan: angka yang diikui oleh huruf kecil yang sama menunjukkan berbeda tidak nyata pada uji BNT 5\%

Berdasarkan Tabel 1. menunjukkan bahwa perlakuan kontrol (P1) berbeda tidak nyata dengan perlakuan perendaman air suhu $45^{\circ} \mathrm{C}(\mathrm{P} 2)$ dan P2 tidak berbeda nyata dengan perlakuan $\mathrm{P}_{3}$ namun $\mathrm{P} 1$ berbeda nyata dengan $\mathrm{P}_{3}$. Perlakuan dengan air suhu $45^{\circ} \mathrm{C}$ memiliki persentase daya berkecambah sebesar $93,75 \%$ tidak berbeda jauh dengan perlakuan $\mathrm{GA}_{3}$ yaitu $100 \%$, menurut (Situmeang et al., 2014) menyatakan bahwa perlakuan suhu perendaman $45^{\circ} \mathrm{C}$ meghasilkan daya berkecambah tertinggi pada benih kedelai yaitu $95,15 \%$ selain itu juga dapat mengurangi serangan patogen jenis jamur. Sedangkan Hasil rerata pada parameter daya berkecambah menunjukkan bahwa perlakuan $\mathrm{GA}_{3}\left(\mathrm{P}_{3}\right)$ memberikan nilai tertinggi yaitu $100 \%$, hal ini terjadi karena perlakuan $\mathrm{GA}_{3}$ dengan konsentrasi yang tepat akan memberikan pengaruh yang lebih tinggi. Sesuai dengan pernyataan (Rajiman, 2018);(Lestari et al., 2016), bahwa zat perangsang tumbuh (giberelin) dapat berpengaruh terhadap daya berkecambah sesuai dengan fungsinya yaitu aktif dalam konsentrasi rendah yang dapat merangsang pembelahan sel dan pemanjangan sel. Sejalan dengan hasil penelitian (Abdulhalem, 2020), bahwa pemberian giberelin dapat meningkatkan persentase perkecambahan dan mempersingkat waktu memulai 
perkecambahan dibandingkan dengan kontrol pada tanaman adas manis.

Menurut(Dewi, 2015), bahwa pemberian $\mathrm{GA}_{3}$ dengan konsentrasi 30 ppm memberikan persentase daya berkecambah tertinggi pada tanaman kedelai yaitu 99\%. Giberelin memiliki peran penting dalam dua proses utama pematahan dormansi yaitu proses pelunakan endosperem dan meningkatkan pertumbuhan embrio sehingga radikula lebih mudah menembus kulit biji (Solichatun, 2016). Perkecambahan benih dimulai dengan penyerapan air oleh benih yang kemudian terjadi pemecahan cadangan makanan dalam biji selanjutnya mobilisasi cadangan makanan lebih lanjut dan mulai terjadi pembelahan dan pembesaran sel sehingga radikula mengalami pemanjangan dan keluar dari kulit biji, kemudian terjadi peningkatan pengambilan air dan pemanjangan aksis embrionik (Weitbrecht et al., 2011). Proses masuknya air ke dalam biji (imbibisi) menjadi faktor utama yang memicu terjadinya perkecambahan, air yang diserap oleh biji berfungsi untuk aktivasi proses metabolisme sel seperti aktivasi enzim, pelunakan kulit biji dan pemecahan cadangan makanan (Bentsink \& Koornneef, 2008).

\section{Kecepatan tumbuh (\%/etmal)}

Perhitungan kecepatan tumbuh dimulai melalui jumlah pertambahan kecambah normal setiap hari selama periode perkecambahan yaitu mulai hari ke-5 sampai hari ke-8 setelah semai. Kecepatan tumbuh dihitung dalam satuan persen per etmal (\%/etmal). Berdasarkan hasil sidik ragam menunjukkan perlakuan ketinggian tempat memberikan pengaruh berbeda nyata $(*)$ terhadap kecepatan tumbuh bunga telang sehingga perlu dilakukan uji lanjut. Berikut hasil uji BNT $5 \%$ perlakuan ketinggian tempat terhadap kecepatan tumbuh dapat dilihat pada Tabel 2 .
Tabel 2. Hasil Uji Lanjut Perlakuan Ketinggian Tempat Terhadap Parameter Kecepatan Tumbuh (\%/etmal) Bunga Telang

\begin{tabular}{cc}
\hline $\begin{array}{c}\text { Perlakua } \\
\mathrm{n}\end{array}$ & $\begin{array}{c}\text { Kecepatan Tumbuh } \\
(\% / \text { etmal })\end{array}$ \\
\hline $\mathrm{K}_{2}$ & $12,66 \mathrm{a}$ \\
$\mathrm{K}_{1}$ & $22,01 \mathrm{~b}$ \\
\hline
\end{tabular}

Keterangan: angka yang diikuti oleh huruf kecil yang sama menunjukkan berbeda tidak nyata pada uji BNT 5\%.

Berdasarkan Tabel 2. menunjukkan perlakuan asal benih dari dataran rendah $\left(\mathrm{K}_{1}\right)$ mempunyai rerata tertinggi yaitu $22 \% /$ etmal, sedangkan ketinggian tempat dari dataran tinggi $\left(\mathrm{K}_{2}\right)$ menunjukkan nilai rerata terendah yaitu $12,66 \%$ /etmal. Artinya $\mathrm{K}_{2}$ berbeda nyata terhadap $\mathrm{K}_{1}$ pada parameter kecepatan tumbuh. Kecepatan tumbuh yang berasal dari dataran rendah memberikan pengaruh nyata, hal ini diduga karena adanya perbedaan morfologi benih seperti ukuran dan berat benih. hal ini sesuai dengan (Sudrajat, 2010), Asal benih berpengaruh nyata terhadap morfologi benih, untuk benih yang berasal dari dataran yang lebih tinggi memiliki ukuran yang lebih besar, hal ini disebabkan oleh faktor lingkungan seperti curah hujan dan ketinggian tempat. Benih yang memiliki kulit benih yang lebih tebal mempunyai daya dan kecepatan tumbuh yang lebih rendah. Hal ini sejalan dengan pernyataan (Singh et al., 2006) bahwa panjang biji, lebar biji dan berat biji dipengaruhi oleh ketinggian tempat asal benih tersebut. Selanjutnya hasil penelitian (Vesela et al., 2020) bahwa benih yang berasal dari dataran rendah memberikan nilai yang lebih tinggi dan lebih cepat dalam perkecambahan dibandingkan dengan asal benih dataran tinggi, hal ini dapat disebabkan oleh periode vegetasi yang lebih lama di dataran rendah sehingga benih dapat tumbuh dan berkembang 
dengan baik(Milbau et al., 2009;Meineri et al., 2013).

\section{Keserempakan Tumbuh (\%)}

Berdasarkan hasil sidik ragam menunjukkan bahwa perlakuan ketinggian tempat $(\mathrm{K})$ memberikan pengaruh berbeda nyata $(*)$ pada parameter keserempakan tumbuh bunga telang sehingga dilakukan uji lanjut. Berikut hasil uji BNT 5\% perlakuan Ketinggian tempat $(\mathrm{K})$ terhadap keserempakan tumbuh dapat dilihat pada Tabel 3.

Tabel 3. Hasil Uji Lanjut Ketinggian Tempat Terhadap Parameter Keserempakan Tumbuh (\%) Bunga Telang

\begin{tabular}{cc}
\hline Perlakuan & Keserempakan Tumbuh (\%) \\
\hline $\mathrm{K}_{2}$ & $45,83 \mathrm{a}$ \\
$\mathrm{K}_{1}$ & $79,17 \mathrm{a}$ \\
\hline
\end{tabular}

Keterangan: angka yang diikuti oleh huruf kecil yang sama menunjukkan berbeda tidak nyata pad uji BNT 5\%

Berdasarkan Tabel 3. dapat dilihat bahwa perlakuan asal benih dari dataran rendah dan dataran tinggi memberikan pengaruh berbeda tidak nyata tetapi $\left(\mathrm{K}_{1}\right)$ memiliki nilai keserempakan tumbuh tertinggi yaitu 79,17\%. Kecepatan tumbuh yaitu ketinggian tempat dari dataran rendah memiliki nilai tertinggi daripada benih yang berasal dari dataran tinggi. Hasil penelitian(Vesela et al., 2020), bahwa benih yang berasal dari dataran rendah memberikan nilai yang lebih tinggi dan lebih cepat dalam perkecambahan dibandingkan dengan asal benih dataran tinggi, hal ini dapat disebabkan oleh periode vegetasi yang lebih lama di dataran rendah sehingga benih dapat tumbuh dan berkembang dengan baik(Milbau et al., 2009; Meineri et al., 2013). Keserempakan tumbuh ditunjukkan oleh nilai dari parameter vigor benih yang menggambarkan potensi benih untuk cepat tumbuh, munculnya seragam dan pengembangan bibit normal dalam berbagai kondisi lapangan. Keserempakan tumbuh yang tinggi mengidentifikasikan vigor kekuatan tumbuh absolut yang tinggi karena suatu lot benih yang menunjukkan serempak dan kuat akan memiliki kekuatan tumbuh yang tinggi (Lesilolo et al., 2018).

\section{Tinggi Tanaman (cm)}

Berdasarkan hasil sidik ragam bahwa perlakuan (P) tidak memberikan pengaruh nyata pada pengamatan tinggi tanaman umur 1 MST, 3 MST, 4 MST dan 5 MST, namun pada umur 2 MST perlakuan (P) memberikan pengaruh berbeda nyata $(*)$ sehingga dilakukan uji lanjut. Berikut hasil uji BNT 5\% perlakuan terhadap parameter tinggi tanaman umur 2 MST.

Tabel 4. Hasil Uji Lanjut Perlakuan terhadap Parameter Tinggi Tanaman Umur 2 MST.

\begin{tabular}{cc}
\hline Perlakuan & Tinggi Tanaman $(\mathrm{cm})$ \\
\hline $\mathrm{P}_{2}$ & $16,74 \mathrm{a}$ \\
$\mathrm{P}_{1}$ & $17,38 \mathrm{a}$ \\
$\mathrm{P}_{3}$ & $19,78 \mathrm{~b}$ \\
\hline
\end{tabular}

Keterangan: angka yang diikuti oleh huruf kecil yang sama menunjukkan berbeda tidak nyata pada uji BNT taraf 5\%

Berdasarkan Tabel 4. dapat diketahui bahwa perlakuan perendaman air suhu $45^{\circ} \mathrm{C}\left(\mathrm{P}_{2}\right)$ berbeda tidak nyata dengan perlakuan kontrol $\left(\mathrm{P}_{1}\right)$ namun $\mathrm{P}_{2}$ dan $\mathrm{P}_{1}$ berbeda nyata dengan $\mathrm{P}_{3}$. Perlakuan perendaman dengan $\mathrm{GA}_{3}\left(\mathrm{P}_{3}\right)$ memberikan nilai tertinggi yaitu $19,78 \mathrm{~cm}$ dan perlakuan kontrol $\left(\mathrm{P}_{1}\right)$ memberikan nilai terendah yaitu $16,74 \mathrm{~cm}$. Hasil penelitian (AL-Shahmani \& Al-Tufaili, 2020), bahwa pemberian giberelin memberikan nilai rerata tertinggi terhadap parameter tinggi tanaman kemangi. Pengaplikasian giberelin juga memberikan pengaruh nyata pada parameter tinggi tanaman kacang hijau umur 3 dan 5 MST (Rosman et al., 2019). Hal ini sejalan dengan pernyataan 
(Moncada et al., 2020), pemberian larutan giberelin memberikan nilai tertinggi pada parameter tinggi tanaman dibandingkan dengan perlakuan kontrol pada tomat dan tanaman cabai merah (Yeni \& Mulyani, 2014).

Peningkatan tinggi tanaman dapat disebabkan oleh giberelin yang merangsang pertumbuhan batang tanaman, aplikasi giberelin merangsang pemanjangan batang tanaman dengan menginduksi pembentukan enzim amilase yang menghidrolisis pati, sehingga meningkatkan kadar gula dan tekanan osmosis cairan sel, kemudian air masuk kedalam sel dan sel memanjang sehingga meningkatkan panjang batang (Setiawan \& Wahyudi, 2014). Namun pada umur 3 MST, 4 MST dan 5 MST tidak memberikan pengaruh terhadap parameter tinggi tanaman. hal ini terjadi karena setiap tanaman melakukan fotosintesis sampai tingkat tertentu sebagai respon terhadap lingkungan dan kepekaan fotosintesis di antara spesies tanaman dan kultivar berbeda-beda (Lin et al., 2021). Menurut (Sufardi, 2020), bahwa pertumbuhan tanaman dipengaruhi oleh faktor genetik dan lingkungan. Faktor genetik dapat mempengaruhi proses fisiologi dan morfologi tanaman (Wang et al., 2019).

\section{Jumlah Daun (helai)}

Berdasarkan hasil sidik ragam menunjukkan bahwa perlakuan asal benih (K) memberikan pengaruh nyata pada parameter jumlah daun umur 1 MST, 2 MST, 3 MST, 4 MST dan 5 MST, sehingga dilakukan uji lanjut. Berikut hasil uji BNT $5 \%$ asal benih terhadap parameter jumlah daun.

Tabel 5. Hasil Uji Lanjut BNT 5\% Asal Benih Terhadap Parameter Jumlah Daun

\begin{tabular}{cccccc}
\hline \multirow{2}{*}{ Perlakuan } & \multicolumn{5}{c}{ Jumlah Daun (helai) } \\
\cline { 2 - 6 } & $1 \mathrm{MST}$ & $2 \mathrm{MST}$ & $3 \mathrm{MST}$ & $4 \mathrm{MST}$ & $5 \mathrm{MST}$ \\
\hline $\mathrm{K}_{2}$ & $0,67 \mathrm{a}$ & $7,00 \mathrm{a}$ & $16,42 \mathrm{a}$ & $35,50 \mathrm{a}$ & $66,08 \mathrm{a}$ \\
\hline $\mathrm{K}_{1}$ & $2,17 \mathrm{a}$ & $9,42 \mathrm{a}$ & $21,83 \mathrm{a}$ & $44,33 \mathrm{~b}$ & $81,50 \mathrm{a}$ \\
\hline
\end{tabular}

Keterangan: angka yang diikuti oleh huruf kecil yang sama menunjukkan berbeda tidak nyata pada uji BNT $5 \%$

Tabel 5. menunjukkan bahwa asal benih dari dataran rendah $\left(\mathrm{K}_{1}\right)$ berbeda nyata terhadap asal benih dari dataran tinggi $\left(\mathrm{K}_{2}\right)$ pada umur 4 MST, namun memberikan pengaruh berbeda tidak nyata pada umur 1 MST, 2 MST, 3 MST dan 5 MST. Hasil penelitian (Supriyanto et al., 2017), bahwa perbedaan asal benih dan lingkungan yang berbeda akan mempengaruhi sifat genetik dan pertumbuhan tanaman. hal ini sejalan dengan (Tsedalu et al., 2014), bahwa asal benih berpengaruh signifikan terhadap pertumbuhan tanaman yaitu tinggi dan jumlah daun tanaman.

\section{KESIMPULAN}

Berdasarkan hasil penelitian dapat disimpulkan bahwa:
- Tidak ada pengaruh interaksi antara asal benih dan berbagai perlakuan pematahan dormansi terhadap parameter daya berkecambah, kecepatan tumbuh, keserempakan tumbuh, tinggi tanaman dan jumlah daun.

- Asal benih dapat meningkatkan kecepatan tumbuh sebesar 22,01\%/etmal, keserempakan tumbuh sebesar 79,17\%, jumlah daun umur 1 MST sebesar 2,17 helai, umur 2 MST sebesar 9,42 helai, umur 3 MST sebesar 21,83 helai, umur 4 MST 44,33 helai, dan umur 5 MST sebesar 81,50 helai.

Perlakuan pematahan dormansi dengan $\mathrm{GA}_{3}$ dapat meningkatkan daya 
berkecambah sebesar $100 \%$ dan tinggi tanaman umur 2 MST sebesar 19,77 cm.

\section{DAFTAR PUSTAKA}

Abdulhalem, A. G. (2020). Effect of gibberellin and saponins extract of Sanscevierialeaves onanise seeds germination. Plant Archives, 20(1), 1045-1050.

AL-Shahmani, N. S. K., \& Al-Tufaili, A. K. H. (2020). The effect of gibberellin and tryptophan on some vegetative and qualitative characteristics of sweet basil. Plant Archives, 20, 18911894.

Amri, E. (2010). The effects of pre-sowing seed treatments on germination of snake bean (Swartzia madagascariensis); a reported Medicinal Plant. Research Journal of Agriculture and Biological Science, 8(5), 525-529. http://www.idosi.org/aejaes/jaes8(5)/ 8.pdf

Balai Penelitian Tanaman Rempah dan Obat. (2020). Selain Cantik Ini Segudang Manfaat Bunga Telang. Balittro.

Bentsink, L., \& Koornneef, M. (2008). Seed Dormancy and Germination. The Arabidopsis Book, 6, e0119. https://doi.org/10.1199/tab.0119

Budiasih, K. S. (2017). Kajian Potensi Farmakologis Bunga Telang (Clitoria ternatea). Prosiding Seminar Nasional Kimia UNY, 21(4), 183188.

Cook, B. ., Pengelly, B., Brown, S., Donnelly, J., Eagles, D., Franco, M., Hanson, B., Mullen, I., Partridge, M., Peters, \& Schultze-Kraft. (2005). Tropical forages. CSIRO, DPI\&F (QId), CIAT and ILRI, Brisbane, Australia.

Dalimartha, S. (2008). Atlas Tumbuhan Obat Indonesia Jilid 5 (5th ed.). Pustaka Bunda.
Dewi, L. permasi. (2015). Pengaruh Konsentrasi ZPT GA3 dan Lama Perendaman Benih terhadap Pertumbuhan dan Hasil Tanaman Kacang Hijau (Phaseolus vilgari) Varietas Sriti. Agroswagati, 3(1).

Heuzé, V., Tran, G., Boval, M., Bastianelli, D., \& Lebas, F. (2016). Butterfly pea (Clitoria ternatea). Feedipedia. http://www.feedipedia.org/node/318[ $08 / 12 / 2016$

Lesilolo, M. ., Riry, J., \& Matatula, E. . (2018). Pengujian Viabilitas Dan Vigor Benih Beberapa Jenis Tanaman Yang Beredar Di Pasaran Kota Ambon. Agrologia, 2(1), 1-9. https://doi.org/10.30598/a.v2i1.272

Lestari, D., Linda, R., \& Mukarlina. (2016). Pematahan Dormansi dan Perkecambahan Biji Kopi Arabika ( Coffea arabika L . ) dengan Asam Sulfat (H2SO4) dan Giberelin (GA3). Jurnal Protobiont, 5(1), 8-13.

Lin, K. H., Huang, M. Y., \& Hsu, M. H. (2021). Morphological and physiological response in green and purple basil plants (Ocimum basilicum) under different proportions of red, green, and blue LED lightings. Scientia Horticulturae, 275(July 2019), 109677. https://doi.org/10.1016/j.scienta.2020 .109677

Manjula, P., Mohan, C., Sreekanth, D., Keerthi, B., \& Prathibha Devi, B. (2013). Phytochemical Analysis of Clitoria Ternatea Linn., a Valuable Medicinal Plant. J. Indian Bot. Soc, 92(4),

173-178. http://www.indianbotsoc.org/admin/u ploaded/9 P MANJULA.pdf

Meineri, E., Spindelböck, J., \& Vandvik, V. (2013). Seedling emergence responds to both seed source and recruitment site climates: A climate change experiment combining transplant and gradient approaches. Plant Ecology, 214(4), 607-619. 
https://doi.org/10.1007/s11258-0130193-y

Milbau, A., Graae, B. J., Shevtsova, A., \& Nijs, I. (2009). Effects of a warmer climate on seed germination in the subarctic. Annals of Botany, 104(2), 287-296.

https://doi.org/10.1093/aob/mcp117

Moncada, A., Vetrano, F., Esposito, A., \& Miceli, A. (2020). Fertigation management and growth-promoting treatments affect tomato transplant production and plant growth after transplant. Agronomy, 10(10). https://doi.org/10.3390/agronomy101 01504

Mukherjee, P. K., Kumar, V., Kumar, N. S., \& Heinrich, M. (2008). The Ayurvedic medicine Clitoria ternateaFrom traditional use to scientific assessment. Journal of Ethnopharmacology, 120(3), 291301.

https://doi.org/10.1016/j.jep.2008.09. 009

Ponnusamy, S., Gnanaraj, W. E., \& Antonisamy, J. M. (2015). Flavonoid Profile of Clitoria ternatea Linn. Majalah Obat Tradisional, 19(1), 15.

https://doi.org/10.22146/tradmedj.80 83

Rajiman, R. (2018). Pengaruh Zat Pengatur Tumbuh (ZPT) Alami Terhadap Hasil Dan Kualitas Bawang Merah. Prosiding Seminar Nasional Fakultas Pertanian UNS, 2(1), A--327. http://jurnal.fp.uns.ac.id/index.php/se mnas/article/view/1068/839

Rosman, A. S., Kendarto, D. R., \& Dwiratna, S. (2019). Jurnal Pertanian Tropik Jurnal Pertanian Tropik. Pengaruh Penambahan Berbagai Komposisi Bahan Organik Terhadap Karakteristik Hidroton Sebagai Media Tanam, 6(2), 180-189. https://jurnal.usu.ac.id/index.php/Tro pik\%0APengaruh
Setiawan, \& Wahyudi, A. (2014). Effect of gibberellin on growth of several pepper varieties in rapid multiplication method. Bulletin Littro, 25(2), 111-118.

Singh, B., Bhatt, B. P., \& Prasad, P. (2006). Variation in seed and seedling traits of Celtis australis, a multipurpose tree, in Central Himalaya, India. Agroforestry Systems, 67(2), 115-122. https://doi.org/10.1007/s10457-0042948-x

Situmeang, M., Purwantoro, A., \& Sulandari, S. (2014). The Effect of Heat Treatment on Germination and Health of Soybean Seed (Glycine max (L.) Merrill). 3(3), 27-37.

Solichatun. (2016). Dormansi Dan Perkecambahan Biji Flamboyan [Delonix regia (Hock) Raf.] Ditinjau Dari Aspek Anatomis, Fisiologis Dan Biokimiawi (Disertasi). Universitas Gadjah Mada.

Sudrajat, D.J., M. (2010). Variation of Seed Morphology and Germination Pre Treatment Response from Five Populations of Sawo Kecik (Manilkara kauki (L.) Dubard). Jurnal Penelitian Hutan Tanaman, 7(2), 67-76.

Sufardi, S. (2020). Pertumbuhan tanaman. Researchgate, May, 126.https://www.researchgate.net/publ ication $/ 341540066$.

Supriyanto, Siregar, I. Z., Suryani, A., Aminah, A., \& Sudrajat, D. J. (2017). Keragaman morfologi buah, benih dan bibit pongamia (Pongamia pinnata (L) Pierre) di Pulau Jawa. Jurnal Perbenihan Tanaman Hutan, 5(2), 103-114.

Sutedi, E. (2013). Potensi Kembang Telang ( Clitoria ternatea ). Wartazoa, 16002, 51-62.

Tsedalu, M., Tesfaye, B., \& Goa, Y. (2014). Effect of Type of Planting Material and Population Density on Corm Yield and Yield Components of 
Taro ( Colocasia Esculenta L .). Journal of Biology, Agriculture and Healthcare, 4(17), 124-138.

United States Departement of Agriculture. (2020). Plants Profile for Clitoria ternatea (Asian pigeonwings). https://plants.usda.gov/core/profile?s ymbol=CLTE3

Vesela, A., Duongova, L., \& Munzbergova, Z. (2020). Plant Origin Determines Seed Mass, Seed Nutrients and Germination Behavior of a Dominant Grass Species. 4(24), 2018-2020.

http://biorxiv.org/content/early/2020/ 12/23/2020.12.01.407460.abstract

Wang, F. yong, Han, H. yong, Lin, H., Chen, B., Kong, X. hui, Ning, X. zhu, Wang, X. wen, Yu, Y., \& Liu, J. de. (2019). Effects of planting patterns on yield, quality, and defoliation in machine-harvested cotton. Journal of Integrative Agriculture, 18(9), 20192028. https://doi.org/10.1016/S20953119(19)62604-3

Weitbrecht, K., Müller, K., \& LeubnerMetzger, G. (2011). First off the mark: Early seed germination. Journal of Experimental Botany, 62(10), 3289-3309. https://doi.org/10.1093/jxb/err030

Yeni, T., \& Mulyani, H. (2014). Pengaruh Induksi Giberelin Terhadap Pertumbuhan Dan Produksi Tanaman Cabai Merah (Capsicum annum L) Sebagai Sumber Belajar Biologi. BIOEDUKASI (Jurnal Pendidikan Biologi), 5(1). https://doi.org/10.24127/bioedukasi. v5i1.258 